\title{
Effects of logging and line planting treatment on canopy openness in logged- over forests in Bornean lowland dipterocarp forest
}

\author{
Tomoya Inada ${ }^{1 *}$, Widiyatno Ano $^{2}$, Suryo Hardiwinoto ${ }^{2}$, Ronggo Sadono ${ }^{2}$, Priyo Eko Setyanto ${ }^{3}$, Saminto \\ and Mamoru Kanzaki ${ }^{1}$ \\ ${ }^{1}$ Graduate School of Agriculture, Kyoto University, Kyoto, Kyoto, 606-8502, Japan \\ ${ }^{2}$ Faculty of Forestry, Gadjah Mada University, Yogyakarta, 55281, Indonesia \\ ${ }^{3}$ PT. Sari Bumi Kusuma, Palangkaraya, 73111, Central Kalimantan, Indonesia \\ * Corresponding author: inada@kais.kyoto-u.ac.jp
}

\begin{abstract}
In logged-over forests, altered light conditions with logging induce pioneer species invasion and reduce commercial value. In Indonesia, reduced impact logging (RIL) methods have been applied to mitigate the logging effects, and line planting of useful species has been conducted in some production forests. However, quantitative assessments of canopy openings during RIL and line planting treatment are insufficient. Line plating involves 3-m strip cutting lines. The effects of these methods on canopy openness are poorly understood. This study assessed the effects of different logging systems on light conditions using hemispherical photographs taken in plots set in primary forests, forest logged over using RIL, and forest treated with strip cutting after RIL. Photographs were also taken along strip cutting lines. The comparison of canopy openness among the three types of sites revealed that logging activities had significant effects on light condition. High levels of canopy openness were found along skid trails and logging gaps following the trails. Therefore reducing the impact on light conditions should be considered when planning skid trails. Between the logged-over forest plots with and without the strip cutting lines, there was no significant difference in the mean canopy openness. However, strip cutting treatment affected to sun fleck duration in the forest floor. It might influence to following dynamics. And there were large differences in canopy openness along each line which would cause variations in the growth of planted trees.
\end{abstract}

Key words: Reduced-impact logging, dipterocarp forest, light condition, hemispherical photograph, line planting

\section{INTRODUCTION}

The continued loss of tropical forests has created interest in the conservation of residual primary forests and the establishment of sustainable forest management in production forests (FAO 2011). In tropical South-East Asia, the main commercial timber species are Dipterocarpaceae, which is dominant family in primary lowland forests (Ashton 1988, Appanah and Weinland 1993, MauryLechon and Curtet 1998). Therefore, the regeneration of dipterocarps after logging is important for sustainability. To achieve sustainable forest management, reduced impact logging (RIL) methods are being applied to logging activities in these forests. This method was designed to reduce damage to forest and to enhance the natural regeneration of desired dipterocarp species while suppressing invasions of pioneers. With RIL methods, canopy openness (CO) is decreased compared to conventional logging by using planned skid trails, well-trained workers, and other criteria (Pereira et al. 2002). Dipterocarp seedlings require partial shading, but need more light as they reach maturity after establishment (Mauricio 1987, Ashton 1998). Moderate gap openings may assist natural regeneration and stimulate growth of dipterocarps (Tuomela et al. 1996). However, some debate exists regarding the efficiency of RIL for the rehabilitation of dipterocarps (Fredericksen and Putz 2003, Sist and Brown 2004).

In recent years in tropical Asia, enrichment planting using line planting of useful species is used to reintroduce commercial species into logged-over secondary forests. It is a practical way to increase the stem density of desired species when the seed bank or mother trees are insufficient or located heterogeneously for regeneration (Sovu et al. 2010). In this method, strip cutting is conducted to allow sunlight to reach planted seedlings to enhance growth. This method is expected to be useful in sustainable forest management, but knowledge about the line planting method is still limited (Ramos and del Amo 1992, Ádjers et al. 1995, Kammesheidt et al. 2003). For planted trees, light condition is an important factor influencing survival and 
growth (Tuomela et al. 1996, Romell et al. 2008).

Light conditions in a forest floor determine seedling establishment and growth and the survival of residual trees (Denslow 1987). The solar radiation required for growth differs among tree species (Whitmore 1990). In and around gaps, many species respond to the change in light conditions according to their biological characteristics (Romell and Karlsson 2009). In particular, Macaranga spp., which are primary pioneer species (Slik et al. 2002, Slik and Eichhorn 2003), may invade and compete with planted dipterocarp seedlings in gaps created by strip cutting. Changes in the microclimate because of canopy opening also affect abiotic factors such as soil moisture and nutrient availability, and influence regeneration dynamics (Brown 1993, Sovu et al. 2010). Therefore, assessing the effects of strip cutting on light conditions on the forest floor is important for sustainability. Quantitative evaluations, however, are insufficient.

Canopy openness and net solar radiation on the forest floor depend on the spatial canopy structure (Montgomery and Chazdon 2001, Silbernagel and Moeur 2001). In logged-over forests, strip cutting was applied from north to south, creating a specific "linear" gap regime that may be different from typical logging gaps. Specifically, with almost the same degree of $\mathrm{CO}$, the duration of exposure to direct sunlight may be different because the sun passes from east to west. Such a different light condition after logging may induce different dynamics. This study aims to assess the effects of RIL and strip cutting treatment on the light condition of forest floor. To achieve it, we conducted hemispherical canopy photography in primary forests and logged-over forests in which the two logging systems (RIL only or RIL and strip cutting) were applied, to assess the difference of the effects on light condition between those two logging systems. In addition, we took photographs along strip cutting lines to assess the effect of this treatment on the light conditions.

\section{MATERIAL AND METHOD}

\section{Study site}

This study took place in an active logging concession in Central Kalimantan province managed by Sari Bumi Kusuma, logging company $\left(00^{\circ} 36^{\prime}-01^{\circ} 10^{\prime} \mathrm{S}, 111^{\circ} 39^{\prime}\right.$ $\left.-112^{\circ} 25^{\prime} \mathrm{E}\right)$. The forest type is lowland dipterocarp forest (Whitmore, 1990). The main commercial species are dipterocarps, especially trees of the genus Shorea, including Shorea leprosula, S. johorensis, and S. parvifolia. They are also main canopy trees. The canopy was about $20 \mathrm{~m}$ high, excluding emergent trees. Since 1998, the RIL method has been applied to logging activity. Line planting has been used since 1999. Mean annual precipitation was $3240 \mathrm{~mm}$ from 2001 to 2009 .

\section{Plot setting}

In the concession area, three sites were selected for hemispherical photography. First, a primary forest site was chosen as a control (PF site; 00 $38^{\prime} 54^{\prime \prime} \mathrm{S}, 112^{\circ} 13^{\prime} 04^{\prime \prime} \mathrm{E}$ ). To evaluate the effects of logging activities (i.e. logging gaps, skid trails and strip cutting), two photography sites were set in logged-over forests that were logged using different logging systems in 2011. One site was a loggedover forest that targeted trees were more than $50 \mathrm{~cm}$ diameter at breast height (DBH) using selective logging with RIL methods (S site; $00^{\circ} 51^{\prime} 16^{\prime \prime} \mathrm{S}, 111^{\circ} 59^{\prime} 51^{\prime \prime} \mathrm{E}$ ). The other site was treated with 3-m-wide strip cutting after selective logging with RIL, targeting trees with $\mathrm{DBH}$ values greater than $40 \mathrm{~cm}$ (SL site; $00^{\circ} 51^{\prime} 26^{\prime \prime} \mathrm{S}, 112^{\circ} 00^{\prime} 06^{\prime \prime} \mathrm{E}$ ). At SL, 3-m-wide strip cutting was conducted at 20-25-m intervals from north to south. In the strip cutting line, all of the trees excluding commercial species and understory plants were clearly removed at 6 months after logging. No canopy treatments such as girdling or pruning were performed. Some Shorea species would be planted at $2.5-\mathrm{m}$ intervals along the lines. This study was conducted before the planting.

In each site, a monitoring plot was established and trees were monitored from September to November 2011. The monitoring plots established in the PF, S, and SL sites measured 4, 2.25, and 3 ha, respectively, and the basal areas of trees $>10 \mathrm{~cm}$ were $32,22.9$, and $18.5 \mathrm{~m}^{2} \mathrm{ha}^{-1}$, respectively. At each of the three sites, three $50 \times 50-\mathrm{m}$ plots were placed at random for hemispherical photography. The topography in each plot was measured. The difference in slope position was within about 20 meters except PF3 and S2 (Table 1). At the PF site, plots were chosen in stands with closed canopies. At both of the logged-over sites, trails from logging activities (skid trails and logging gaps) and strip cutting lines were mapped in all plots. Skid trails were approximately 3-4 $\mathrm{m}$ wide. Within a plot, 49 photography points were taken with a $5-\mathrm{m}$ spacing. These $5-\mathrm{m}$ grids were located in the interior of the plot, $10 \mathrm{~m}$ from the plot boundary, to avoid the inclusion of canopy of trees and logging effects located outside the plot. In addition, three strip cutting line transects were chosen near the plots at the SL site. In a strip cutting line, hemispherical photographs were taken with $5-\mathrm{m}$ spacing over $100 \mathrm{~m} ; 21$ photographs were taken per line (Fig. 1). In total, nine plots and three line transects were established. 
Table 1 . Topography at each site

\begin{tabular}{lcl}
\hline \multicolumn{1}{c}{ Plot } & $\begin{array}{c}\text { Difference in slope } \\
\text { position (m) }\end{array}$ & \multicolumn{1}{c}{ Slope aspect } \\
\hline PF1 & 11.8 & South \\
PF2 & 13.9 & Ridge from North to South \\
PF3 & 31.5 & Southeast \\
S1 & 15.8 & Northwest \\
S2 & 21.0 & South east \\
S3 & 15.0 & South \\
SL1 & 20.0 & Northwest \\
SL2 & 16.5 & Northwest \\
SL3 & 12.4 & East \\
Strip cutting line 1 & 14.4 & South \\
Strip cutting line 2 & 9.9 & North \\
Strip cutting line 3 & 1.0 & Almost flat \\
\hline
\end{tabular}

$\mathrm{PF}$, primary forest; $\mathrm{S}$, selective logging; SL, selective logging and line planting

\section{Hemispherical photography}

Hemispherical canopy photography is widely used to assess light conditions (Chazdon and Field 1987, Rich 1989, Rich et al. 1993, Frazer et al. 2001). Hemispherical photographs were taken in October 2011, before planting, about half a year after logging. Photographs were taken on days with uniform overcast skies to avoid sun reflections on vegetation and direct sunshine. The photography equipment included a digital camera (Coolpix 8400; Nikon, Tokyo, Japan) with an attached fisheye converter FC-E9 $0.2 \times$ lens (Nikon). The camera was mounted on a tripod, the lens was set at a height of $1.2 \mathrm{~m}$ and the camera was oriented so that the top of the photograph faced magnetic north. Photographs were taken according to the Open-sky Reference Method (ORM) that Tani et al. (2011) proposed. ISO sensitivity was set to 10,000 . The aperture setting was selected automatically with a shutter speed of $1 / 500 \mathrm{~s}$ under open-sky conditions. Three photographs were taken at each photo point with shutter speeds of $1 / 125,1 / 250$, and $1 / 500 \mathrm{~s}$. Among the three pictures that were taken in each subplot, one picture was selected by visual examination for image analysis.

\section{Image analysis}

Hemispherical photographs were analyzed using Gap Light Analyser (GLA) Ver. 2.02 (Frazer et al. 1999). This software has been used in several studies (Jarčuška 2008). GLA changes photographs to binary images of 'sky' or 'not sky' based on thresholds that refer to an open-sky condition, according to ORM methods. CO was calculated in each of the three sites. The light condition is not determined solely from the CO; the width and direction of the canopy opening are also important. Then, we simulated the cumulative sunfleck duration within 1 year at all three sites and strip cutting lines. The duration was simulated by assuming it was sunny every day at the measured latitude and longitude of each site. As a result, 147 image sets for each site and 63 image sets for cutting lines were analysed.

\section{Statistical analysis}

To evaluate the effects of logging and strip cutting treatment on canopy openness, the statistical differences in the mean $\mathrm{CO}$ among the three sites were assessed using the Kruskal-Wallis test to detect the difference in the distribution of $\mathrm{CO}$ between site S and SL. In addition, from the plot maps, we separated all the photo points into the elements disturbance, intact, skid trail, logging gap, and strip cutting line (SL sites only) and compared the CO among the elements using one-way analysis of variance (ANOVA). When the one-way ANOVA was significant, differences among the elements were determined using Tukey's test. The correlation between the $\mathrm{CO}$ value and simulated cumulative sun-fleck duration for 1 year was analyzed using Pearson's correlation coefficient analysis and single regression for each of the three sites. In addition, the slopes of the regression among three sites and strip cutting line were compared using analysis of covariance (ANCOVA). If the ANCOVA was significant, differences among three sites and strip cutting lines were estimated using Bonferroni's test to evaluate the effects of strip cutting treatment on light condition. The distribution of canopy openness was compared between sites S and SL using twosample Kolmogorov-Smirnov tests, with $\mathrm{P}<0.05$ considered statistically significant.

\section{RESULTS}

\section{CO after logging activities}

In the primary forest, the calculated $\mathrm{CO}$ for all of the photography points was less than $5 \%$ and the mean $\mathrm{CO}$ was $1.79 \pm 0.95 \%$. Mean calculated CO values were $7.57 \pm$ $6.63 \%$ and $7.88 \pm 6.55 \%$ at the S and SL sites, respectively (Table 2). According to the Kruskal-Wallis test, the mean $\mathrm{CO}$ of the primary forest was low compared to those of the two logging sites; no significant difference in $\mathrm{CO}$ was found between sites $\mathrm{S}$ and SL. In the two logged-over sites, the standard deviation suggested large differences in $\mathrm{CO}$ within each site. CO ranged from $0.27 \%$ to $23.82 \%$ at the $\mathrm{S}$ site and from $0.39 \%$ to $27.82 \%$ at the SL site. Fig. 2 shows the distribution of the calculated $\mathrm{CO}$ at each site, using two 

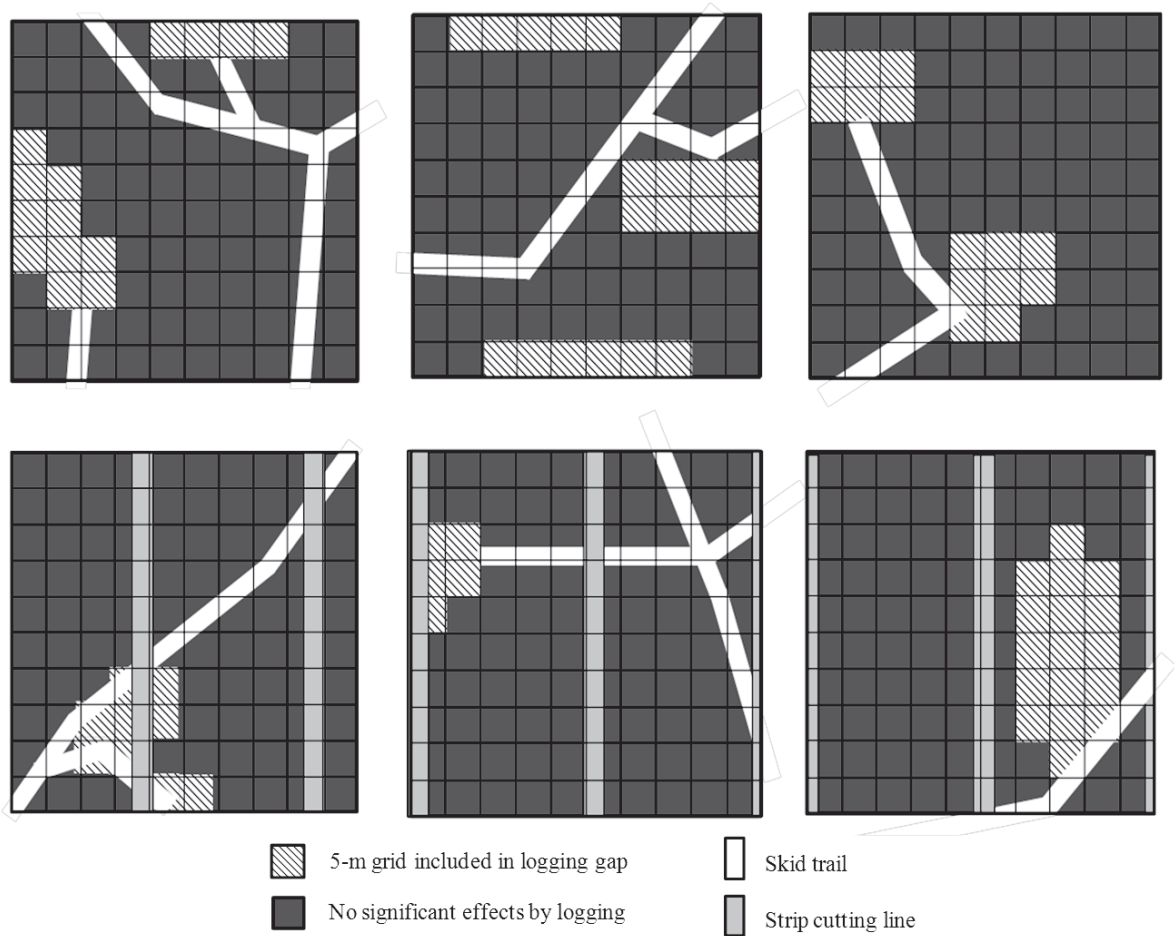

$\square$ Skid trail

Strip cutting line
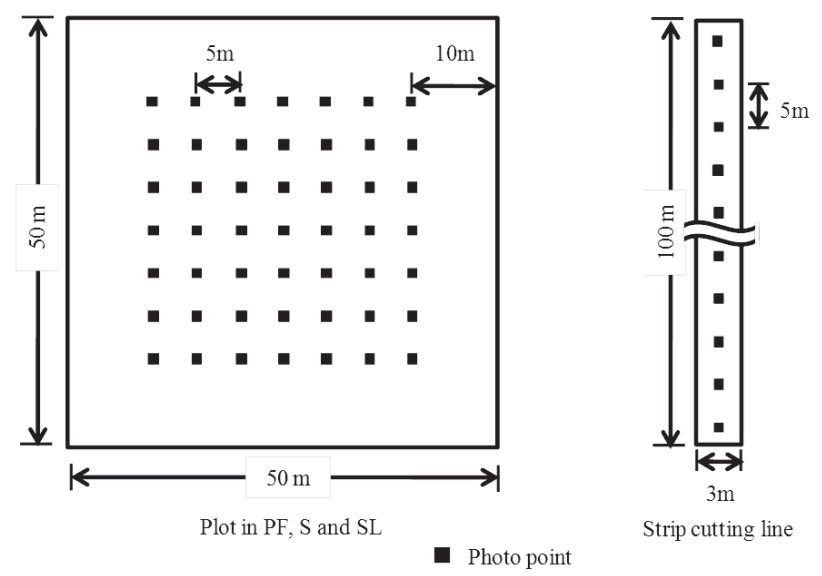

Strip cutting line

Fig. 1. Treatment maps for the selective logging (S) and selective logging and line planting (SL) sites (above) and sample plot schematic showing photography points at each site, PF, primary forest; S, selective logging; SL, selective logging and line planting (below).

fractional scales. Large $\mathrm{CO}$ values were more frequent at site SL compared to site S. However, no significant difference in the $\mathrm{CO}$ distribution was found between sites $\mathrm{S}$ and SL using the Kolmogorov-Smirnov test.

The effect of logging on the canopy was strongly correlated with logging trails (Fig. 3). The distribution of $\mathrm{CO}$ values was dependent on the logging activity conducted in the plot. Comparison of the $\mathrm{CO}$ values measured for each disturbance element showed a significant effect of logging activities on light conditions (Fig. 4). The mean CO was lowest at intact photography points at both sites S and SL. At site $\mathrm{S}$, the mean $\mathrm{CO}$ was highest at the skid trail photo points. In contrast, at site SL, there was no significant difference among the elements, and the strip cutting treatment altered the light conditions.

In strip cutting line, mean $\mathrm{CO}$ was $11.71 \pm 6.6 \%$ from all photography points. No significant differences were detected among the three lines (Table 2). However, considerable variation in $\mathrm{CO}$ was noted within each line. $\mathrm{CO}$ ranged from $2.25 \%$ to $24.82 \%$. In some points, calculated $\mathrm{CO}$ values were almost the same as those in stands with closed canopies. However, many photography points had higher $\mathrm{CO}$ values. In addition, in each line, CO changed gradually and showed a wave-shaped trend (Fig. 5).

\section{Correlation between $\mathrm{CO}$ and sun fleck duration}

Pearson's correlation coefficient analysis found a significant correlation between the $\mathrm{CO}$ value and 
Table 2. Summary of the mean canopy openness for each site and strip cutting line

\begin{tabular}{|c|c|c|c|c|c|c|}
\hline Site & Plot & $N$ & Mean & S.D. & Max. & Min. \\
\hline \multirow{4}{*}{ PF } & 1 & 49 & 1.3 & 0.8 & 4.2 & 0.2 \\
\hline & 2 & 49 & 1.9 & 0.9 & 4.7 & 0.4 \\
\hline & 3 & 49 & 2.2 & 0.8 & 4.2 & 1.1 \\
\hline & All & 147 & 1.8 & 1.0 & 4.7 & 0.2 \\
\hline \multirow{4}{*}{ S } & 1 & 49 & 4.2 & 3.9 & 13.1 & 0.3 \\
\hline & 2 & 49 & 9.4 & 6.2 & 21.3 & 1.5 \\
\hline & 3 & 49 & 9.1 & 8.0 & 23.8 & 0.3 \\
\hline & All & 147 & 7.6 & 6.6 & 23.8 & 0.3 \\
\hline \multirow{4}{*}{ SL } & 1 & 49 & 8.9 & 5.6 & 19.5 & 0.5 \\
\hline & 2 & 49 & 4.0 & 1.4 & 8.3 & 1.2 \\
\hline & 3 & 49 & 10.7 & 8.5 & 27.3 & 0.4 \\
\hline & All & 147 & 7.9 & 6.6 & 27.3 & 0.4 \\
\hline \multirow{4}{*}{$\begin{array}{l}\text { Strip } \\
\text { cutting } \\
\text { line }\end{array}$} & 1 & 21 & 11.0 & 6.1 & 19.1 & 2.3 \\
\hline & 2 & 21 & 11.7 & 7.4 & 23.8 & 2.8 \\
\hline & 3 & 21 & 12.4 & 6.5 & 24.8 & 4.8 \\
\hline & All & 63 & 11.7 & 6.6 & 24.8 & 2.3 \\
\hline
\end{tabular}

PF, primary forest; S, selective logging; SL, selective logging and line planting cumulative sun-fleck duration for 1 year at the three sites and strip cutting line (Fig. 6). From the multiple comparisons, there were statistical differences in the slope among three sites and strip cutting line. The slope was highest in site S, followed by site SL, and followed by strip cutting line. Lowest slope was found in site PF.

\section{DISCUSSION}

Effects of logging activity on light conditions on the forest floor

Mean CO in primary forest stands was very low $(<5 \%)$, which is explained by the presence of high multilayer canopies (Silbernagel and Moeur 2001, Romell and Karlsson 2009). In the two logged-over forests, logging activities and strip cutting treatment induced major changes in light conditions. Both in site $\mathrm{S}$ and $\mathrm{SL}$, skidding and accompanying logging gaps changed the light condition significantly.

Skidding was the largest factor altering the light condition. In logged-over forest, when 8-15 trees are extracted per hectare, typically $15-40 \%$ of the area is traversed by bulldozer paths (Chai 1975, Jusoff 1991). Therefore, to suppress the impact on the light condition, it is necessary to reduce the number and area of skid trails.
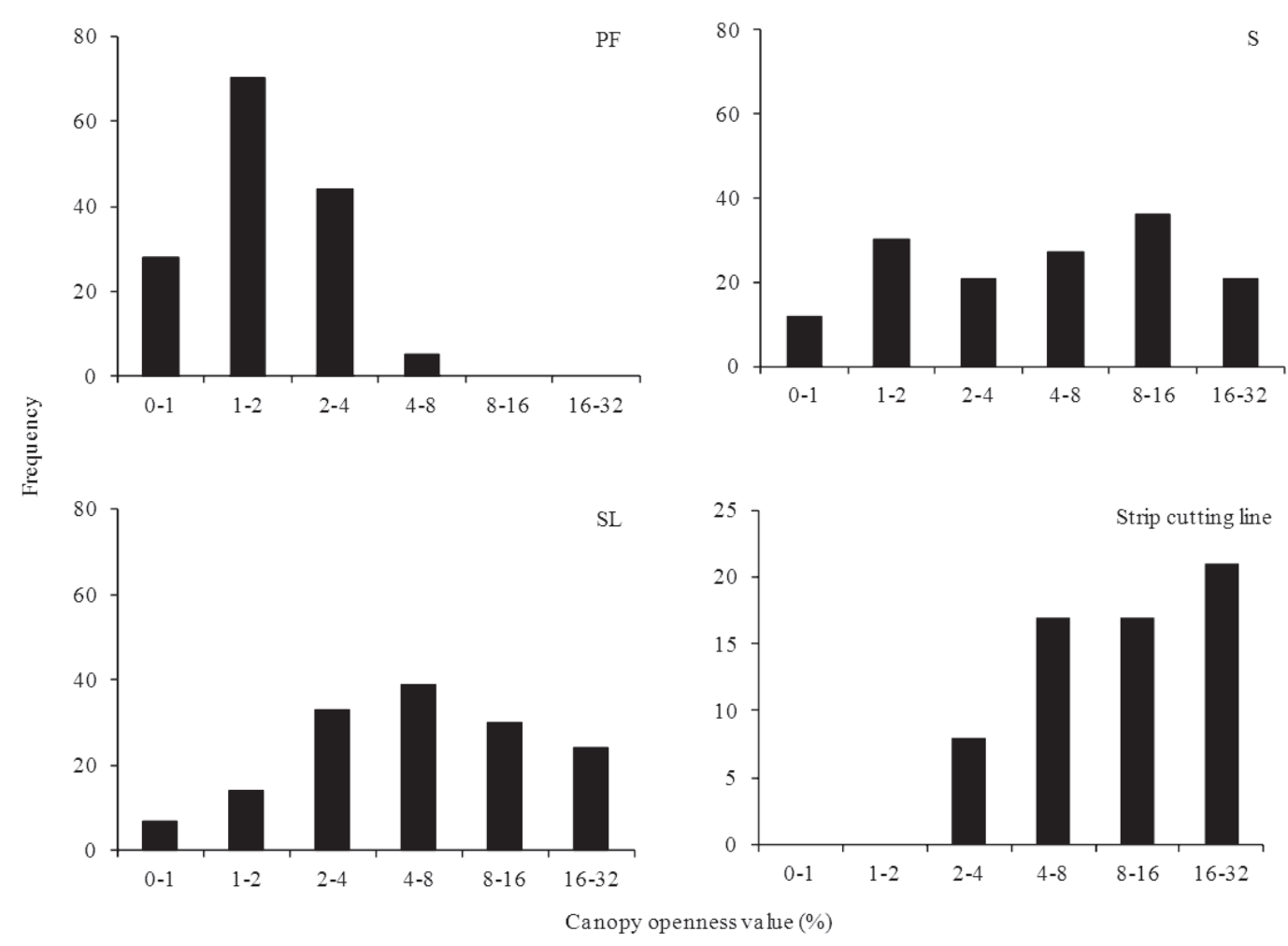

Fig. 2. Frequency distribution of the canopy openness (\%) for all photography points at each site. PF, S, SL, and strip cutting line. 

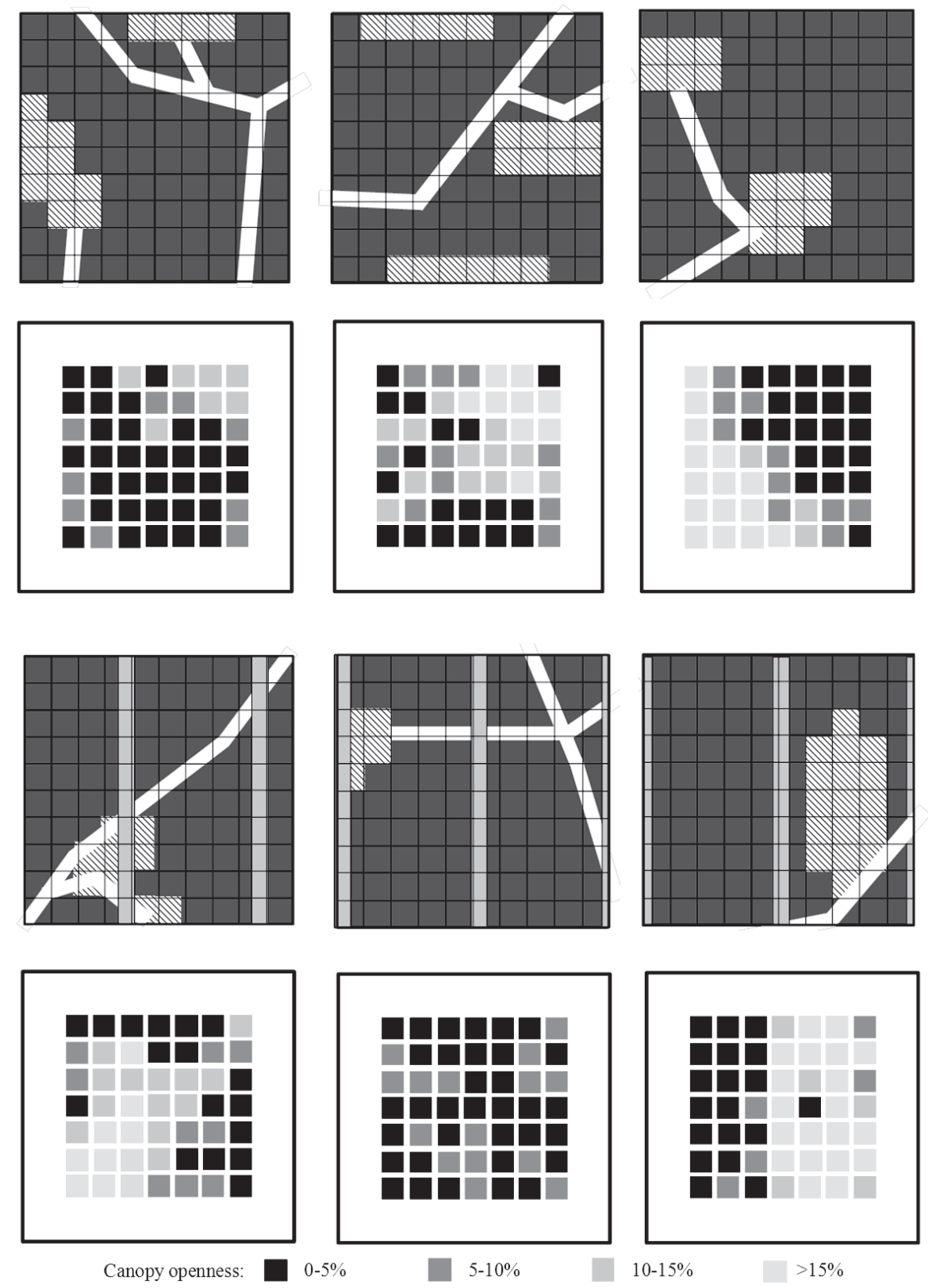

Fig. 3. Logging trail maps and distributions of canopy openness (\%) calculated from those images in each plots at S and SL site. Graph legends for the plots are same as Fig. 1.

Planning efficient skidding and log pulling (winching) from skid trails were recommended (Supriyatno and Becker 1999).

Logging gap was also a main factor altering the light condition. The effect depended on logging intensity (Sist et al. 2003). And it was heterogeneous and varied enormously, being related to the size of each gaps. From the plot maps, there was variation in the size (Fig. 3), and it depends on the logged tree size and canopy condition of neighboring trees.

Although high $\mathrm{CO}$ was measured in strip cutting lines, significant effect on the canopy openness was not found in mean $\mathrm{CO}$ value and the distribution from the comparison between site S and SL (Table 2, Fig. 2).

In the two logged-over forests, mainly logging activities changed the light condition. Both in site S and SL, however, large CO values (i.e. 16-32\%) were not found frequently. Efficiency of RIL for suppressing large canopy opening was reported in previous study (Sist et al. 2003). RIL was considered that functioned well for reducing the impact on canopy openness.

The strip cutting treatment did not affect the canopy 

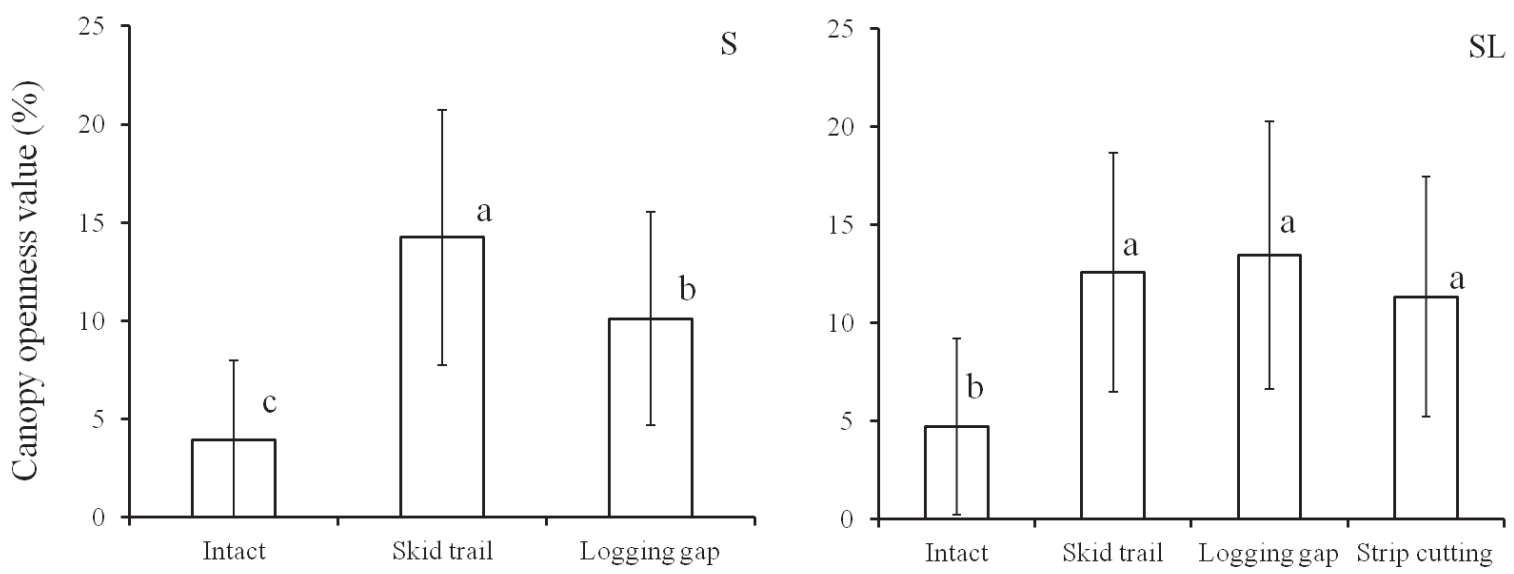

Elements of disturbance

Fig. 4. Comparison of canopy openness among the logging elements in the selective logging (S) and selective logging and line planting (SL) sites. Different letters indicate statistical differences among the logging elements at each sites using Tukey's test.
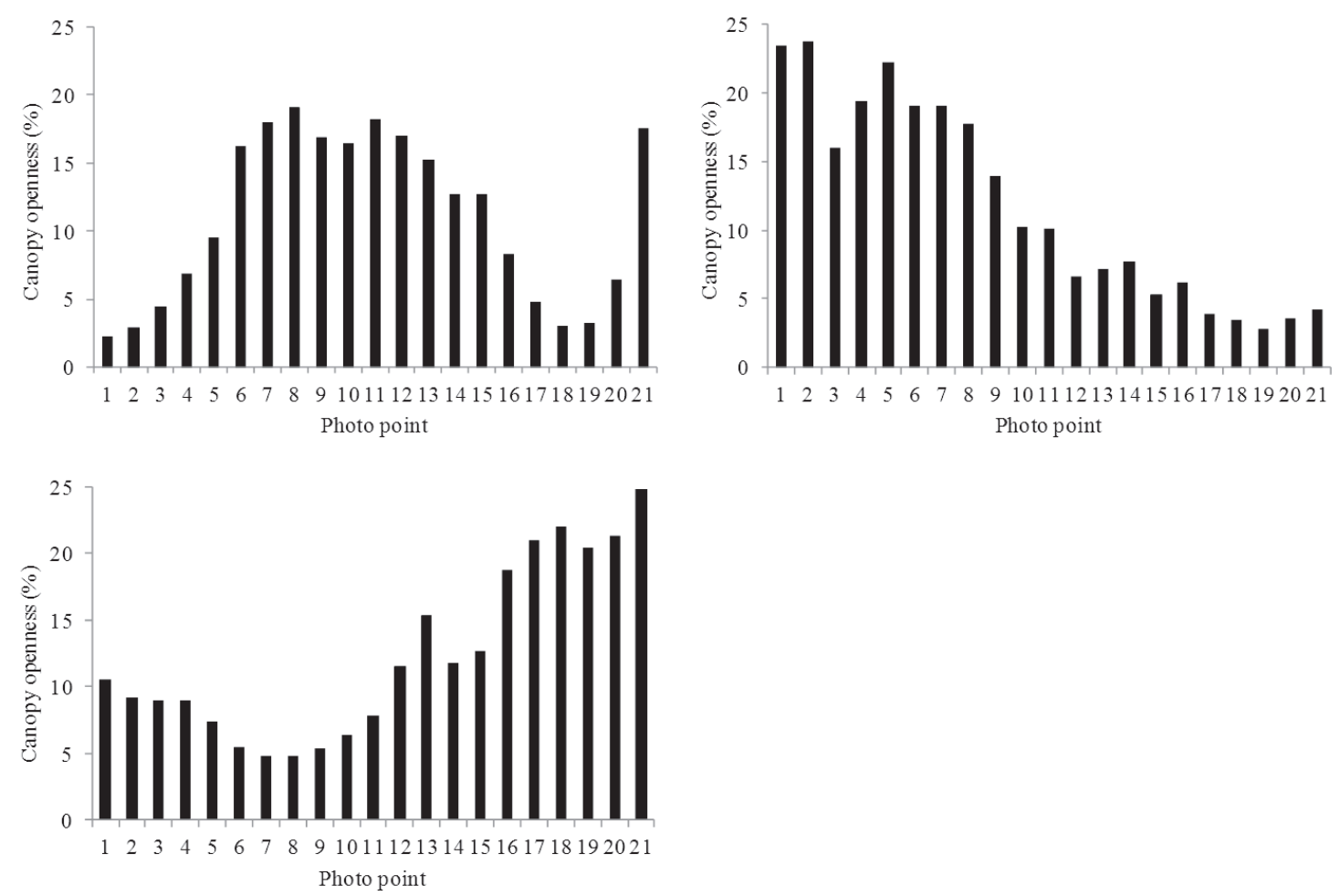

Fig. 5. Distribution of canopy openness for $100 \mathrm{~m}$ in each of three strip cutting lines. Photo points were counted from the south end of each line.

openness as the whole forest stands. However, the effect of the treatment on the light condition was found in sun-fleck duration in the forest floor. Cumulative sun-fleck duration was strongly correlated with $\mathrm{CO}$. Comparing three sites and strip cutting line, there were statistical differences in the slope of the regression. There was a difference in the cumulative sun-fleck duration for the same $\mathrm{CO}$ by different logging systems. The slope was highest in site $\mathrm{S}$, and it in the strip cutting line was significantly low. It suggested that in same CO condition, the solar radiation was relatively short in strip cutting lines compared to logging gaps. The treatment scheme of strip cutting in this study was 3-m-wide cuts from north to south. With the sun pass from East to West, relatively short solar radiation was found in the "linear" gap created by strip cutting treatment. The slope in site SL was statistically low compared to site S. It 

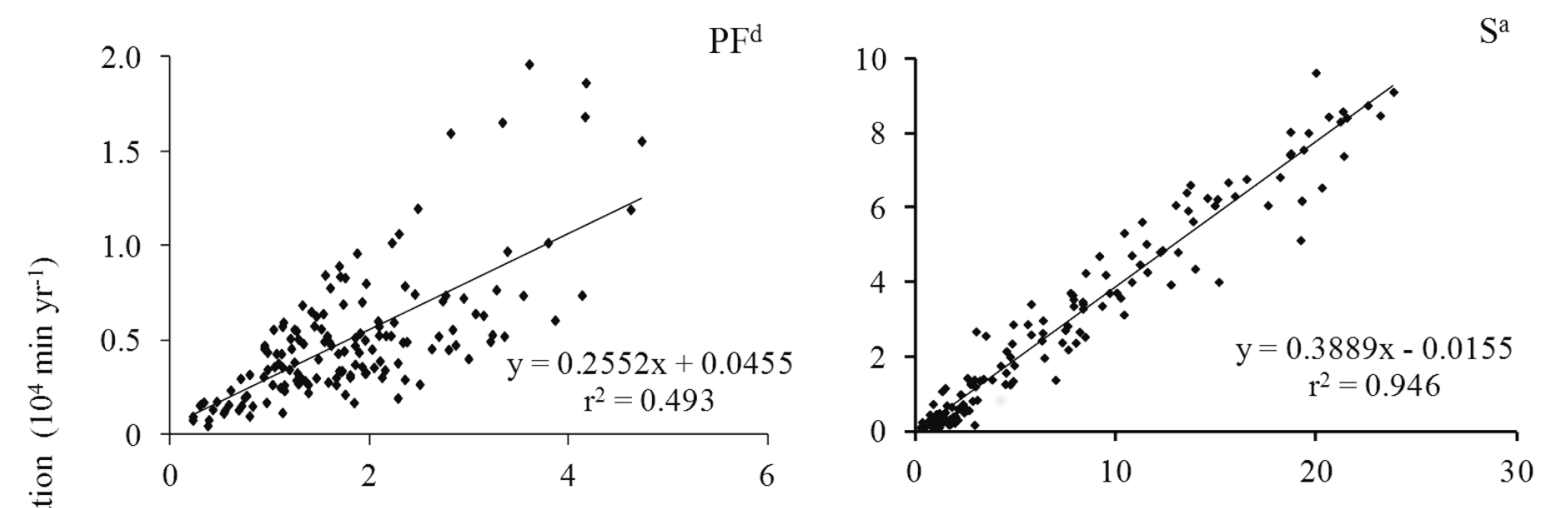

$\mathrm{S}^{\mathrm{a}}$
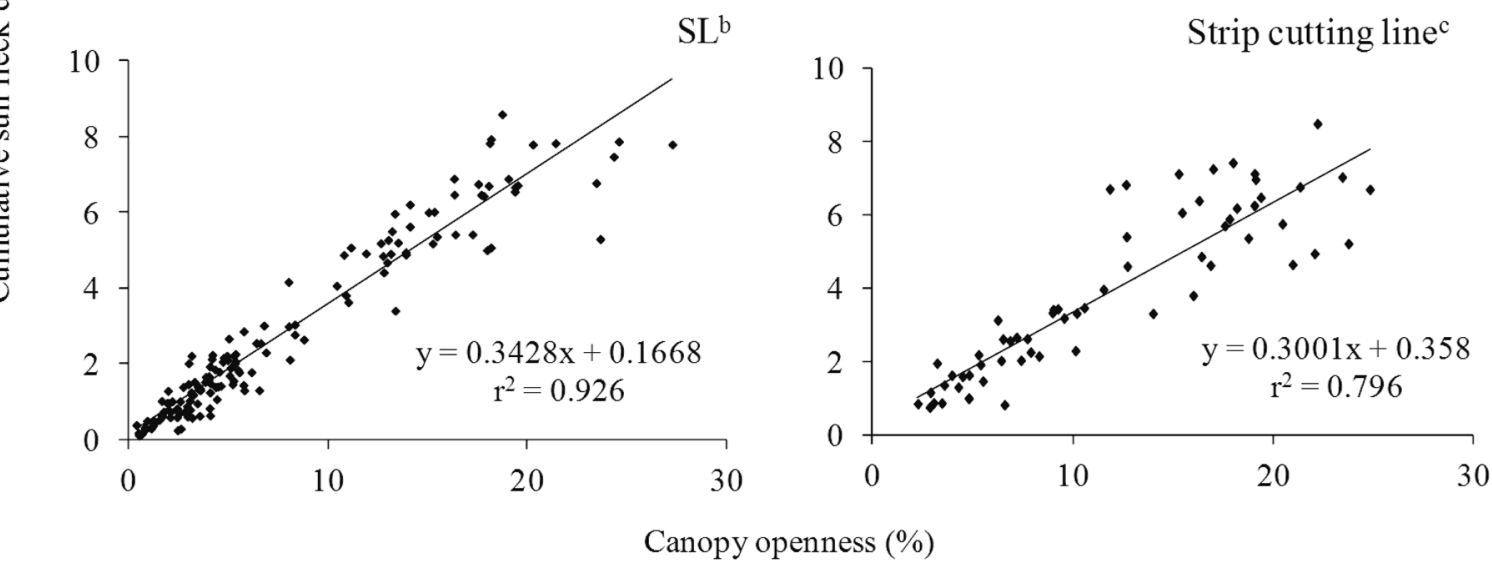

Fig. 6. Scatter diagram of the correlation between the calculated canopy openness and cumulative sun-fleck duration for 1 year at each photography point in the primary forest (PF), selective logging (S), and selective logging and line planting (SL) sites and strip cutting lines. Different letters attached to site name indicates statistical difference in the slope of regression line among the three sites and strip cutting line using Bonferroni's test.

was considered that affected by strip cutting treatment.

Between site $\mathrm{S}$ and SL, there was no statistical difference in the canopy openness by the strip cutting treatment, however it was affected the solar radiation in forest floor. Various light conditions lead to different following seedling establishment and the species composition (Nifinluri et al. 1999). Strip cutting treatment might affect to the following seedling establishment.

\section{Light condition in strip cutting line}

The effect of strip cutting treatment for the light condition was found. According to the biological characteristics of planted light demanding Shorea species, initial light availability is important (Clearwater et al. 1999). Strip cutting treatment was expected as one of the practical method to improve the light condition. However, large differences and a wave-shaped distribution of $\mathrm{CO}$ were observed in each strip cutting line (Table 2, Fig. 6). In this study, no canopy treatment such as girdling or pruning was performed after logging. Trees were only removed along 3-m-wide lines. The difference in slope position in the lines was within 14 meters in most steep line (Table 1). Therefore, the differences in CO under the same strip cutting treatment were dependent on the abundance of neighboring trees and the canopy condition along the line. These initial differences in $\mathrm{CO}$ and following canopy closure can affect the survival and growth of planted seedlings. Canopy gaps close rapidly after at least 6 months in pioneer-dominated forests (Romell and Karlson 2009). To reveal the appropriate light conditions for planted seedlings and enhance the line planting methods, it is necessary to monitor the canopy openness change and the relationship to the planted seedlings by continuous research.

ACKNOWLEDGEMENTS This study was supported by Strategic Funds for the Promotion of Science and Technology of Japan Science and Technology Agency (project title; Creation of a Paradigm for the Sustainable Use of Tropical Rainforest with Intensive Forest Management and Advanced Utilization of Forest Resources) and JSPS KAKENHI Grant Number 22251004. This study would not have been possible without the 
support and cooperation of PT. Sari Bumi Kusuma and PT. Wana Subur Lestari.

\section{REFERENCE}

Ådjers G, Hadengganan S, Kuusipalo J, Nuryanto K, Vesa L. 1995. Enrichment planting of dipterocarps in logged-over secondary forests: effect of width, direction and maintenance method of planting line on selected Shorea species. Forest Ecology and Management 73: 259-270.

Appanah S, Weinland G. 1993. Planting quality timber trees in Peninsular Malaysia: a review. Forest Research Institute Malaysia, Kuala Lumpur.

Ashton PS. 1988. Dipterocarp biology as a window to the understanding of tropical forest structure. Annual Review of Ecology and Systematics 19: 347-370.

Brown N. 1993. The implications of climate and gap microclimate for seedling growth conditions in a Bornean lowland rain forest. Journal of Tropical Ecology 9: 153-168.

Chai DNP. 1975. Enrichment planting in Sabah. Malaysian Forester 38: 271-277.

Chazdon RL, Field CB. 1987. Photographic estimation of photosynthetically active radiation: evaluation of a computerized technique. Oecologia 73: 525-532.

Clearwater MJ, Nifinluri T, van Gardingen PR. 1999. Growth response of wild Shorea seedlings to highlight intensity. In: Sist PS, Sabogal C, Byron Y (eds) Management of Secondary and Logged-over Forests in Indonesia. CIFOR, Bogor, Indonesia. 55-64.

Denslow JS. 1987. Tropical rainforest gaps and tree species diversity. Annual Review of Ecology and Systematics 18: 431-451.

[FAO] Food and Agriculture Organization. 2011. Global Forest Resource Assessment 2010: main report. FAO, Rome.

Frazer GW, Canham CD, Lertzman KP. 1999. Gap Light Analyzer (GLA), Version 2.0: Imaging software to extract canopy structure and gap light transmission indices from truecolour fisheye photographs, users manual and program documentation. Copyright (C) 1999: Simon Fraser University, Burnaby, British Columbia, and the Institute of Ecosystem Studies, Millbrook, New York.

Frazer GW, Fournier RA, Trofymow JA, Hall RJ. 2001. A comparison of digital and film fisheye photography for analysis of forest canopy structure. Agricultural and Forest Meteorology 109: 249-263.

Fredericksen TS, Putz FE. 2003. Silvicultural intensification for tropical forest conservation. Biodiversity and Conservation 12: 1445-1453.

Jarčuška B. 2008. Methodological overview to hemispherical photography, demonstrated on an example of software GLA. Folia Oecologica 35: 66-69.

Jusoff K. 1991. A survey of soil disturbance from tractor logging in a hill forest of Peninsular Malaysia. In: Appanah $\mathrm{S}, \mathrm{Ng}$ FS, Ismail R (eds) Malaysian Forestry and Forest Products
Research. Forest Research Institute Malaysia, Kepong, Malaysia. 16-21.

Kammesheidt L, Dagang AA, Schwarzwäller W, Weidelt HJ. 2003. Growth patterns of dipterocarps in treated and untreated plots. Forest Ecology and Management 174: 437-445.

Mauricio, FP. 1987. Enrichment planting improves logged-over dipterocarp forests: The Philippine experience. In: Kostermans AJGH (eds) Proceedings of the Third Round Table Conference on Dipterocarps. Samarinda, Indonesia. 16-20.

Maury-Lechon G, Curtet L. 1998. Biogeography and evolutionary systematics of Dipterocarpceae. In: Appanah S, Turnbull JM (eds) A Review of Dipterocarps: Taxonomy, ecology and silviculture. CIFOR, Bogor, Indonesia. 5-44.

Montgomery RA, Chazdon RL. 2001. Forest structure, canopy architecture and light transmittance in tropical wet forests. Ecology 82: 2707-2718.

Nifinluri T, Clearwater MJ, van Gardingen P. 1999. Measurement of gap size and understorey light intensities after logging in Central Kalimantan. In: Sist PS, Sabogal C, Byron Y (eds) Management of Secondary and Logged-over Forests in Indonesia. CIFOR, Bogor, Indonesia. 65-70.

Pereira R, Zweede J, Asner GP, Keller M. 2002. Forest canopy damage and recovery in reduced-impact and conventional selective logging in eastern Para, Brazil. Environmental Studies 168: 77-89.

Ramos JM, Amo S del. 1992. Enrichment planting in a tropical secondary forest in Veracruz, Mexico. Forest Ecology and Management 54: 289-304.

Rich PM. 1989. A manual for analysis of hemispherical canopy photography. Los Alamos National Laboratory, Los Alamos, New Mexico.

Rich PM, Clark DB, Clark DA, Oberbauer SF. 1993. Long-term study of solar radiation regimes in a tropical wet forest using quantum sensors and hemispherical photography. Agricultural and Forest Meteorology 65: 107-127.

Romell E, Karlsson A. 2009. Forest floor light conditions in a secondary tropical rain forest after artificial gap creation in northern Borneo. Agricultural and Forest Meteorology, 149: 929-937.

Romell E, Hallsby G, Karlsson A, Garcia C. 2008. Artificial canopy gaps in a Macaranga spp. dominated secondary tropical rain forest - Effects on survival and above ground increment of four under-planted dipterocarp species. Forest Ecology and Management 255: 1452-1460.

Silbernagel J, Moeur M. 2001. Modeling canopy openness and understory gap patterns based on image analysis and mapped tree data. Forest Ecology and Management 149: 217-233.

Sist P, Sheil D, Kartawinata K, Priyadi H. 2003. Reduced-impact logging in Indonesian Borneo: some results confirming the need for new silvicultural prescriptions. Forest Ecology and Management 179: 415-427.

Sist P, Brown ND. 2004. Silvicultural intensification for tropical forest conservation: a response to Fredericksen and Putz. Biodiversity and Conservation 13: 2381-2385.

Slik JW, Verburg RW, Kessler PJA. 2002. Effects of fire and selective logging on the tree species composition of lowland 
dipterocarp forest in East Kalimantan, Indonesia. Biodiversity and Conservation 11: 85-98.

Slik JWF, Eichhorn KAO. 2003. Fire survival of lowland tropical rain forest trees in relation to stem diameter and topographic position. Oecologia 137: 446-455.

Sovu, Tigabu M, Savadogo P, Odén PC, Xayvongsa L. 2010. Enrichment planting in a logged-over tropical mixed deciduous forest of Laos. Journal of Forestry Research 21: 273-280.

Supriyatno N, Becker G. 1999. Secondary Logging in Natural Forests in Central Kalimantan: Operational Design, Production and Damage Assessment. In: Sist PS, Sabogal C, Byron Y (eds) Management of Secondary and Logged-over Forests in Indonesia. CIFOR, Bogor, Indonesia. 81-90.
Tani A, Ito E, Tsujino M, Araki M, Kanzaki M. 2011 Threshold determination by reference to open sky overcomes photographic exposure error in indirect leaf area index estimation. Japanese Journal of Forest Environment 53: 41-52.

Tuomela K, Kuusipalo J, Vesa L, Nuryanto K, Sagala A, Ådjers G. 1996. Growth of dipterocarp seedlings in artificial gaps: An experiment in a logged-over rainforest in South Kalimantan, Indonesia. Forest Ecology and Management 81: 95-100.

Whitmore TC. 1990. An Introduction to Tropical Rain Forests. Oxford University Press, UK.

Received: August 4, 2012 Accepted: April 15, 2013 